\title{
Effect of Vermiaqua and Hospital wastewater on Bitter gourd (Momordica charantia L.)
}

\author{
Neha Verma ${ }^{1 *}$ and Ashok K. Ghosh ${ }^{2}$ \\ ${ }^{1}$ Department of Botany, A. N. College, Patna, India \\ ${ }^{2}$ Bihar State Pollution Control Board, Patna, India \\ *Corresponding author
}

\section{A B S T R A C T}

\section{Keywords}

Momordica

charantia,

Vermifiltration

(VF), Vermiaqua

(VA), Hospital

wastewater

(HWW),

Earthworms

Article Info

Accepted:

12 December 2020

Available Online:

10 January 2021
For the survival of life water is very important and its scarcity is really a very big issue for us and our society. So, its conservation is most important. When any type of untreated wastewater has been discharged into municipal collection system or in rivers and that water is used for irrigation of plants, it affects our ecosystem. Due to which the risks of infection increase because it contains so many organic and inorganic pollutants, pathogens, antibiotics, drug metabolites, microbes and other chemicals. For the purification and reuse of impure water so many physical, chemical and biological techniques have been developed. To overcome these types of problems a new technique vermifiltration is introduced. Vermifiltration is a natural and biological technique that is self-regulated, odourless and cost-effective. In this technique earthworm's species (Eisenia fatida) has been used for purification purpose. They can bio-accumulate toxic substances, different chemicals, antibiotics and drug metabolites in their tissues. Their body works as biofilter because they can disinfect and detoxify different types of wastewater and the resulting filtrate (vermiaqua) is almost neutral, pathogen free and chemical free. The study of Bitter gourd (Momordica charantia L.) showed that vermiaqua promotes plant height, leaf size, flowering, fruiting and seedling growth.

\section{Introduction}

Water is a natural and essential resource for the development of life and other activities of human. The table of underground water is decreasing rapidly all over the world. Presently, its scarcity is a big problem which is a cause of great concern in our society. In the world only $1 \%$ water is potable or usable, $2 \%$ is found in frozen and high hilly areas and $97 \%$ is found in sea areas according to the report of UNEP (United Nation Environment Program). $85 \%$ fresh water is consumed in agriculture but due to the use of chemical fertilizers water demand for the chemically grown crops have increased.

Considering these things, today conservation of water is very important due to which so many techniques have been developed for the purification and reuse of impure water in the world. 
According to epidemiological survey, last 20 years when the untreated wastewater is used for crop production then the risks of infection increases which is caused by pathogens and other chemicals present in wastewater. The chances of infection also increase when untreated hospital wastewater has been discharged in municipal collection system or sewage and that water is used for irrigation purpose (Suarez et. al 2009). Hospital wastewater contains so many materials like pharmaceutical ingredients, drug metabolites, disinfectants, chemical materials, pathogens, and organic matters (Pauwels and Verstraete 2006). To solve this problem reuse of wastewater is an alternative to reduce anthropogenic effects. Hence, it is necessary to develop a suitable method for the removal of these types of pollutants (Carballa et al., 2004). Sewage Treatment Plants (STP) is a wastewater treatment plant which is used for the removal of these types of pollutants. Developing countries can't able to construct and maintain the STP unit because establishment and running cost of Sewage Treatment Plants (STP) are very high.

Various techniques are used for the treatment of wastewater, but these are expensive, space consuming, time consuming, electricity required, different chemicals required and also create air pollution. For the treatment of these kinds of wastewater biological measures are more suitable than the physical and chemical treatment methods. A new biological technique with earthworms has been introduced in the filtration system and is known as vermifiltration system. This is a natural system which saves time, money, electricity, energy, space and chemicals also. It is self-regulated, cost-effective, automated, low electricity, no noise pollution, maintenance free, sludge free, disinfected and detoxified process. There is no sludge formation takes place during vermifiltration of wastewater Thus, it is an eco-friendly system. Technically, vermifiltration is a synergistic and symbiotic activity of earthworms with microorganisms, here worms integrated with organic pollutants, present in wastewater and also increasing surface area which is suitable for the microbial activities and degradation also (Tomar et al.,, 2011, Arora, et al.,,2014 and Samal, et al.,, 2017).

Traditional sewage treatment plants (STPs) are not capable to remove Endocrine disrupting chemicals (EDCs), present in sewage but Earthworms can bio-accumulate it. It has been reported that the high concentrations of EDCs present in the tissues of earthworms specially in E. fetida living in the vermifilter beds and also in garden soil (Markman et al., 2007).

Usually, the body of earthworm functions as a bioreactor. The body of earthworm works as a biofilter that absorbs pollutants present in wastewater and also reduces 95\% BOD, $85 \%$ COD, $95 \%$ TSS, 90-92\% TDS \& 95\% Turbidity and $99 \%$ fecal coliforms (E. coli) from wastewater (Sinha et al., 20012). It also reduces BOD5, COD, TSS about 93\%, $65 \%, 89 \%$ and $\mathrm{pH}$ value are 7.24 from hospital wastewater (Ghobadi et al., 2016).

According to Shokouhi (2020) vermifiltration system is also capable of treating hospital wastewater because it reduces $90 \%$ COD and $90 \%$ BOD from hospital wastewater (Shokouhi et al., 2020).

Vermifiltered water also reduces the environmental risk of antibiotics which is present in hospital wastewater (Shokouhi et al., 2020). Vermifiltered water is almost crystal clear, nearly sterile, neutral $\mathrm{pH}$ value, and also a nutritive organic fertilizer (NPK) which is rich in 2- 3\% Nitrogen $(\mathrm{N}), 1.55$ $2.25 \%$ Phosphorus (P) and $1.85-2.25 \%$ Potassium (K) (Sinha et al., 2008 \& Sinha et al., 2010). 
The raw sewage water creates bad odour and reduces phosphorous from 4-8 to 1-2 ppm and ammonical nitrogen (NH4 -N) from 25-40 ppm to less than $1 \mathrm{ppm}$. In vermifiltered water the content of Nitrates (NO3), Phosphates (P2O5) and Potassium (K) increases from 1020 to $50 \mathrm{ppm}, 1-2$ to $5-7 \mathrm{ppm} \& 10-15$ to 20 25 ppm respectively (Sinha et. al, 2014 \& 2015). Thus, vermifiltered water is highly nutritive and also saves water $\&$ fertilizers so, it is good for agriculture. It also helps the reuse of wastewater water in the society (Kumar and Ghosh 2019).

In this study, we investigated the impact of vermifiltered water and hospital wastewater for the growth of Bitter gourd.

Mechanism of earthworm's action in vermifiltration system

In the vermifiltration system both the microbial and warms process works together. Actually, earthworms promote the growth of decomposer bacteria in hospital waste water. They act as a crusher, grinder, aerator, biological stimulator and chemical degrader, thus its body functions as bioreactor and biofilter (Dash 1978).

In vermifilter bed earthworms feed upon organic and inorganic substances present in wastewater and excrete vermicast. Vermicast increases hydraulic conductivity and adsorption power of vermifilter bed (Bhawalkar 1995). In earthworms Metallothioneins are present which bind metals and make them inactive (Ireland, 1983; Hartenstein et al.,, 1980; Haimi et al.,, 1992).

\section{Materials and Methods}

\section{Designing and Construction of the Vermifiltration unit}

For the construction of vermifiltration unit two plastic drums of 80 liter was taken. Both drums were filled with $25 \mathrm{~cm}$ of large, $25 \mathrm{~cm}$ of middle and $25 \mathrm{~cm}$ of small size gravels. Small size gravels were followed by $25 \mathrm{~cm}$ of sand layer. The top layer was consisting of garden soil with $5 \mathrm{~kg}$ dry cow dung about 35 cm. $1.5 \mathrm{~kg}$ earthworms (Eisenia fetida) were added on the top layer of (one plastic drum) the soil bed known as vermibed but another drum was organized in the same way except earthworms. Hospital wastewater was filtered through this vermifiltration system and collected in pre-treated effluent i.e. filtered water container as shown in Fig. 1. The vermifiltered water (Vermiaqua) was placed at room temperature in dark because light can influence its chemical properties. Vermifiltered water was used for the irrigation of Bitter gourd.

\section{Features of Bitter gourd (Momordica charantia L.)}

Bitter gourd (Momordica charantia L.) $(2 \mathrm{n}=$ 22) is an annual, climbing herb belongs to the family Cucurbitaceae and is originated in Southern China and Eastern India. Its Botanical name is Momordica charantia and English name is Bitter gourd. It has grown extensively in kharif and summer seasons across the country and is consumed as a vegetable. It is a most popular vegetable in India. It possesses medicinal properties like anti-cancer, anti-oxidant, anti-viral, antimicrobial and anti- diabetic properties.

\section{Selection of Bitter gourd (Momordica charantia L.) seeds}

The seed named VNR seed was purchased from Magadh Krishi Kendra, Jamal Road, Patna, India. Use of hospital wastewater and vermiaqua for cultivation and irrigation of Bitter gourd 15 seeds of bitter gourd were sown in 3 different pots equally. First pot was treated with hospital wastewater (HWW), second pot was treated with tap water (C) and third pot was treated with $25 \%$ tap water and 
$75 \%$ vermifiltered water i.e. vermiaqua (VA). Every day $50 \mathrm{ml}$ of each water was poured in all three pots. Hight of all three plants were measured at the interval of 10 days (Fig 2).

\section{Bio- mass estimation}

For the estimation of biomass 10 seedlings were taken and wrapped with aluminium foil. At first fresh weight was taken then dried in oven at $70 \circ \mathrm{C}$ for $48 \mathrm{~h}$ after this dry weight was taken. Biomass was calculated by the subtraction of dry weight from fresh weight and expressed in gram.

\section{Results and Discussion}

\section{Morphological characteristics}

\section{Assessment of plant growth and hight of Bitter gourd}

The graphic presentation of plant height of every 10 days was presented in Fig. 3. The hight of vermiaqua treated plant (VA) was 90 $\mathrm{cm}$, Hospital wastewater treated plant (HWW) was $86 \mathrm{~cm}$ and tap water treated plant (C) was $88 \mathrm{~cm}$ in first month i.e. after 30 day. In second month i.e. after 60 day the hight of VA was $291 \mathrm{~cm}$, HWW was $220 \mathrm{~cm}$ and $C$ was $255 \mathrm{~cm}$. In third month i.e. after 90 day the high of VA was $452 \mathrm{~cm}$, HWW was $370 \mathrm{~cm}$ and $C$ was $410 \mathrm{~cm}$. In fourth month i.e. after 120 day the hight of VA was $632 \mathrm{~cm}$, HWW was $502 \mathrm{~cm}$ and $\mathrm{C}$ was $565 \mathrm{~cm}$. The hight of vermiaqua treated plant was always higher than control and hospital wastewater treated plants. Vermiaqua treated plant looked dark green, big and healthy than control and hospital wastewater treated plants. Hight of HWW treated plant was also increases significantly but it was looking unhealthy than the control and VA treated plants.

\section{Assessment of leaf size of Bitter gourd}

The graphic presentation of leaf size of every
10 days was presented in Fig. 4. The leaf size of plant was increased significantly. In first month i.e. after 30 days the size of vermiaqua treated plant (VA) was $8 \mathrm{~cm}$, Hospital wastewater treated plant $(\mathrm{HWW})$ was $6 \mathrm{~cm}$ and tap water treated plant (C) was $6 \mathrm{~cm}$. In second month i.e. after 60 days the leaf size of VA became $9.5 \mathrm{~cm}$ whereas the leaf size of $\mathrm{C}$ was $8.5 \mathrm{~cm}$ and $\mathrm{HWW}$ was $8 \mathrm{~cm}$. The leaf size of vermitreated plant was bigger than HWW treated plant and tap water treated plant.

\section{Assessment of number of leaves}

The graphic presentation of number of leaves of every 10 days was presented in Fig. 5. In a plant no. of leaves increased whole period of study. No, of branches and sub branches also increased. In vermitreated plants no. of branches and sub branches were more than the HWW and C treated plants. So, VA treated plant becomes so bouncy.

In first month i.e. after 30 days no. of leaves in vermiaqua treated plant (VA) was 40, Hospital wastewater treated plant (HWW) was 35 and tap water treated plant (C) was 38 . In second month i.e. after 60 days no. of leaves of VA was $135 \mathrm{~cm}$ whereas no. of leaves of $\mathrm{C}$ was $110 \mathrm{~cm}$ and $\mathrm{HWW}$ was 98 $\mathrm{cm}$ respectively.

\section{Assessment of flowering behaviour}

The graphic presentation of flowering behaviour of Bitter gourd was presented in Fig. 6. The total number of male flowers per plant up to 30 days after the appearance of first male flower was significantly higher in vermiaqua treated plant (37) in comparison with control treated plant (24) and HWW treated plant (15). The graphic presentation of flowering behaviour of Bitter gourd was presented in Fig. 7. Total number of female flowers were higher in vermiaqua treated plant (31) when compared to control treated 
plant (10) and HWW treated plant (7) up to 30 days after the appearance of the first male flower, per plant. In vermiaqua treated plant (VA) 65 days were taken for the opening of first female flower while in control

(C) it was taken 72 days and in HWW treated plant it took 85 days (Fig. 7).

\section{Assessment of size and weight of fruit}

The graphic presentation of size of Bitter gourd fruit of every 10 days was presented in Fig. 8. The fruit size of vermiaqua treated plant (VA) was $17 \mathrm{~cm}$, Hospital wastewater treated plant (HWW) was $8 \mathrm{~cm}$ and tap water treated plant $(\mathrm{C})$ was $12 \mathrm{~cm}$ after 30 days. The fruit length was significantly higher in vermiaqua treated plant (VA) when compared to Hospital wastewater treated plant (HWW) and tap water treated plant (C). However, width and flesh thickness of fruit showed nonsignificant difference among all three conditions. Width of fruit was higher in vermiaqua treated plant $(5 \mathrm{~cm})$ as compared to Hospital wastewater treated plant $(3 \mathrm{~cm})$ and tap water treated plant $(3.9 \mathrm{~cm})$ (Fig. 9). The fruit weight was also significantly higher in vermiaqua treated plant $(115.20 \mathrm{~g})$ in comparison to Hospital wastewater treated plant $(52.81 \mathrm{~g})$ and tap water treated plant $(70.23 \mathrm{~g})$ as shown in Fig. 10

Fig.1 Vermifiltration unit assembled on the movable iron rack and placed in dark

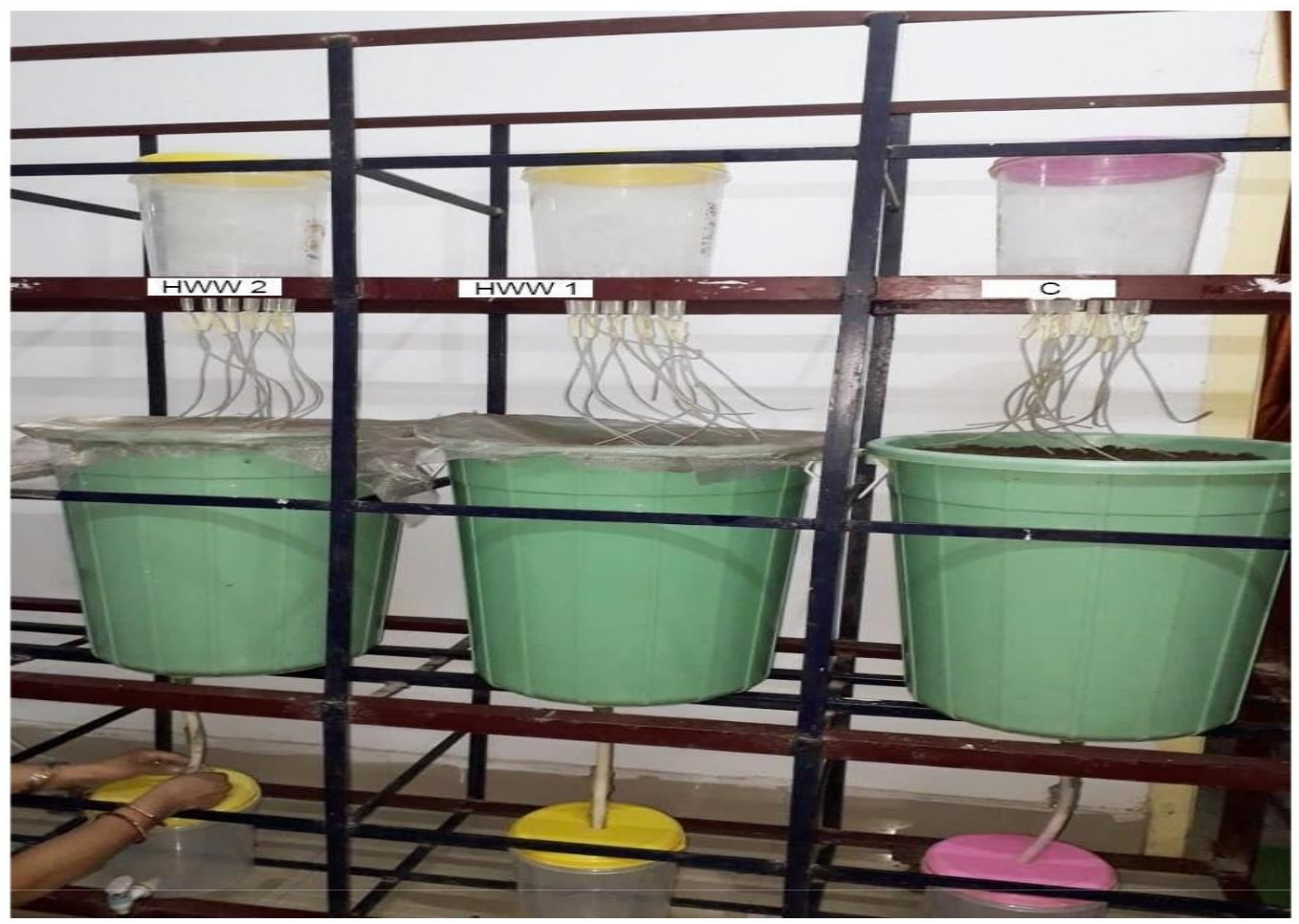


Fig.2 Growth of plant treated with Control, Hospital wastewater and Vermiaqua
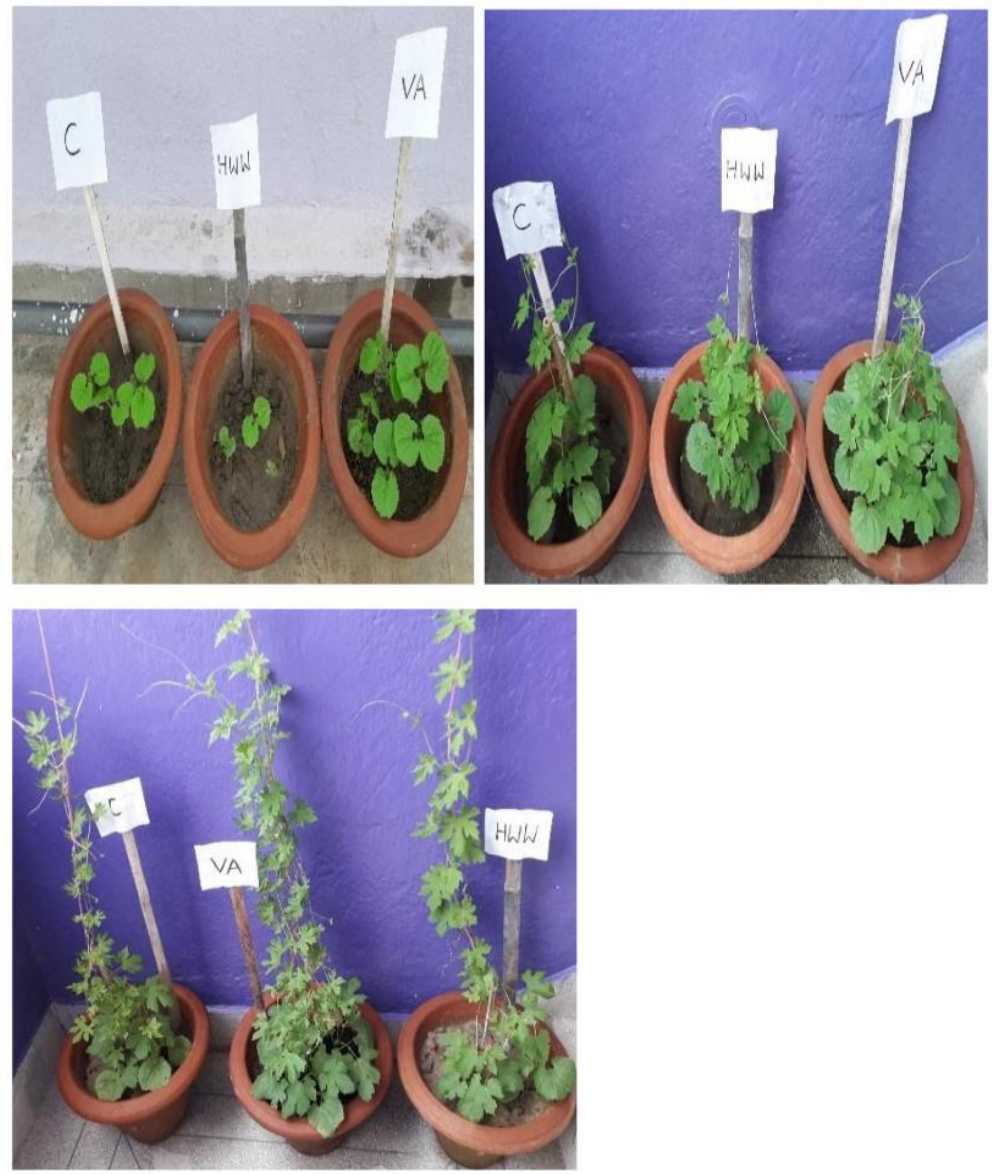

Fig.3 Graphic representation of Plant Height

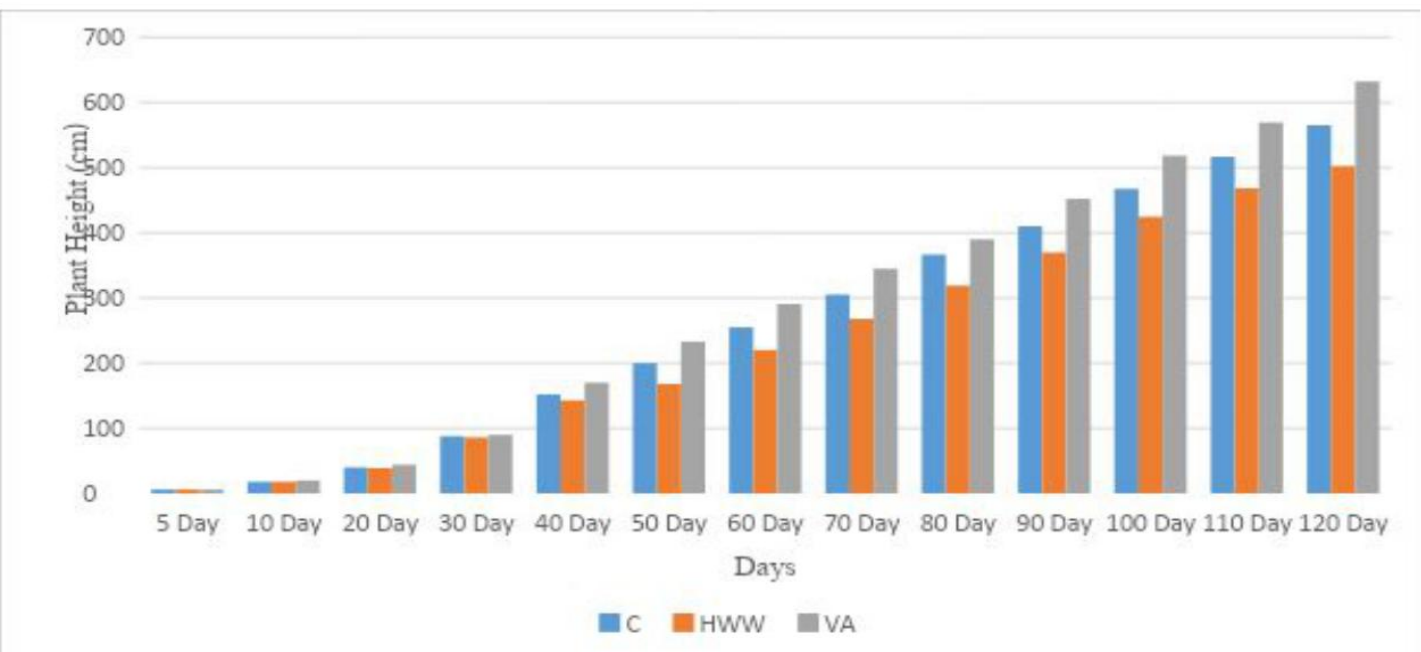


Fig.4 Graphic representation of Leaf Size

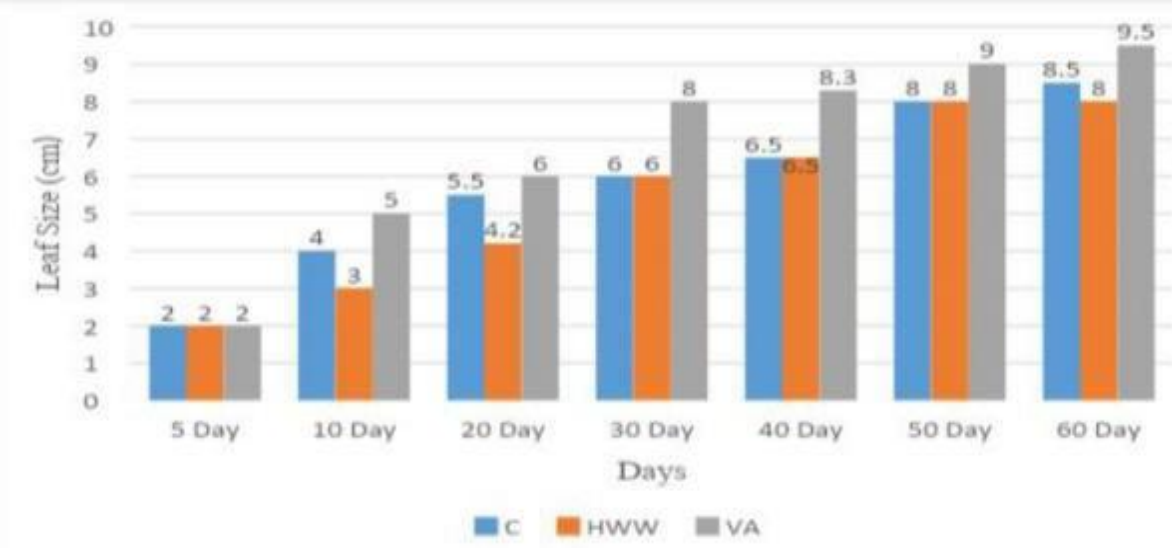

Fig.5 Graphic representation of number of leaves

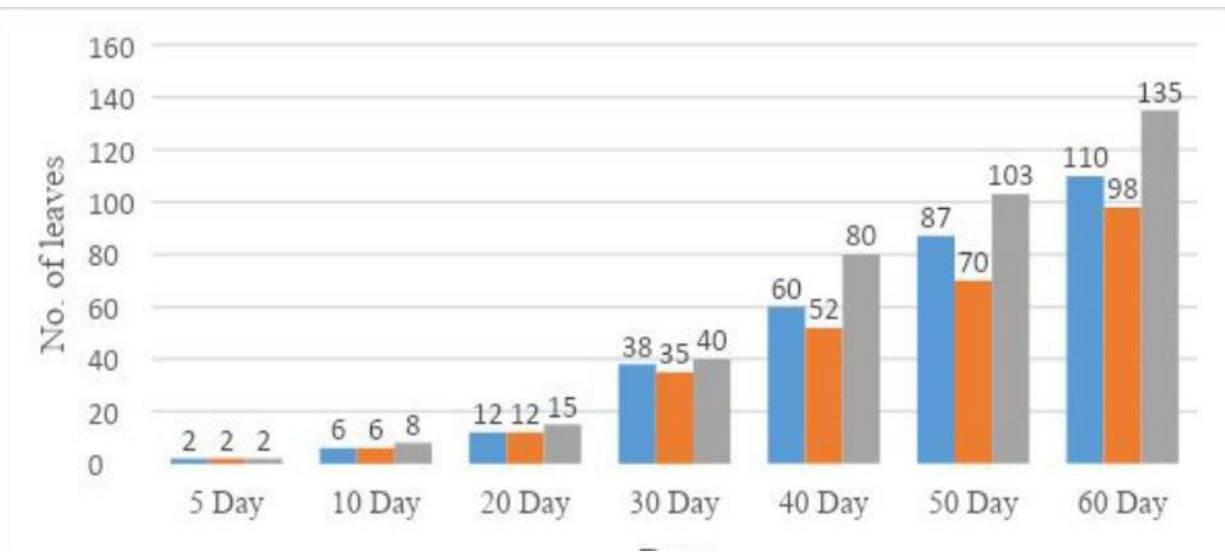

Fig.6 Graphic representation of no. of male and female flower per plant upto 30 days

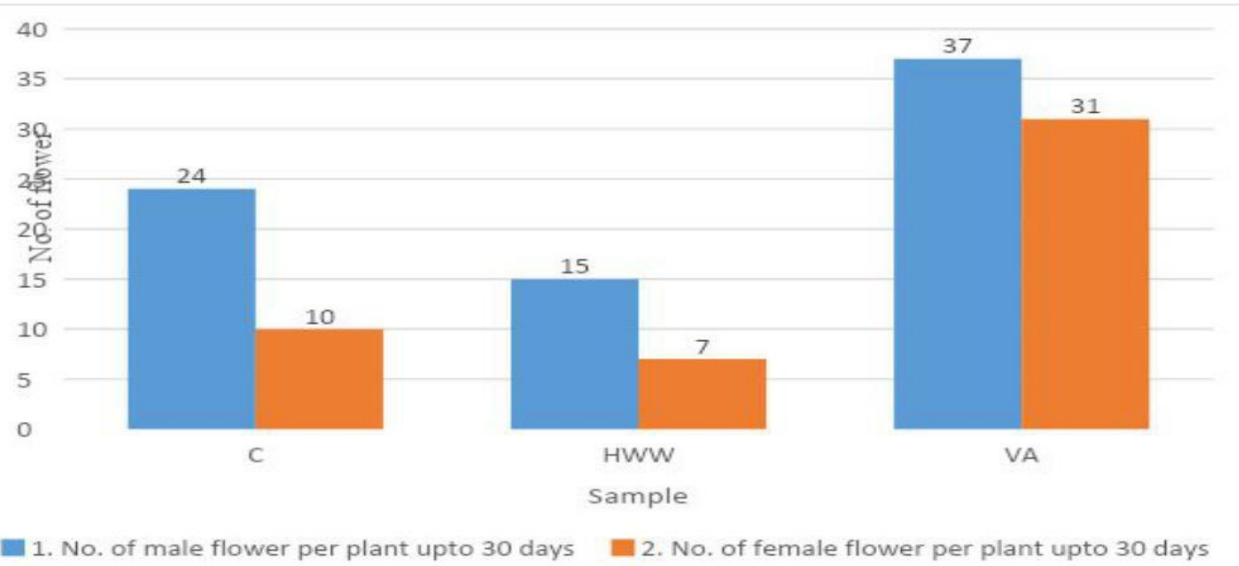


Fig.7 Graphic representation of opening of first female flower

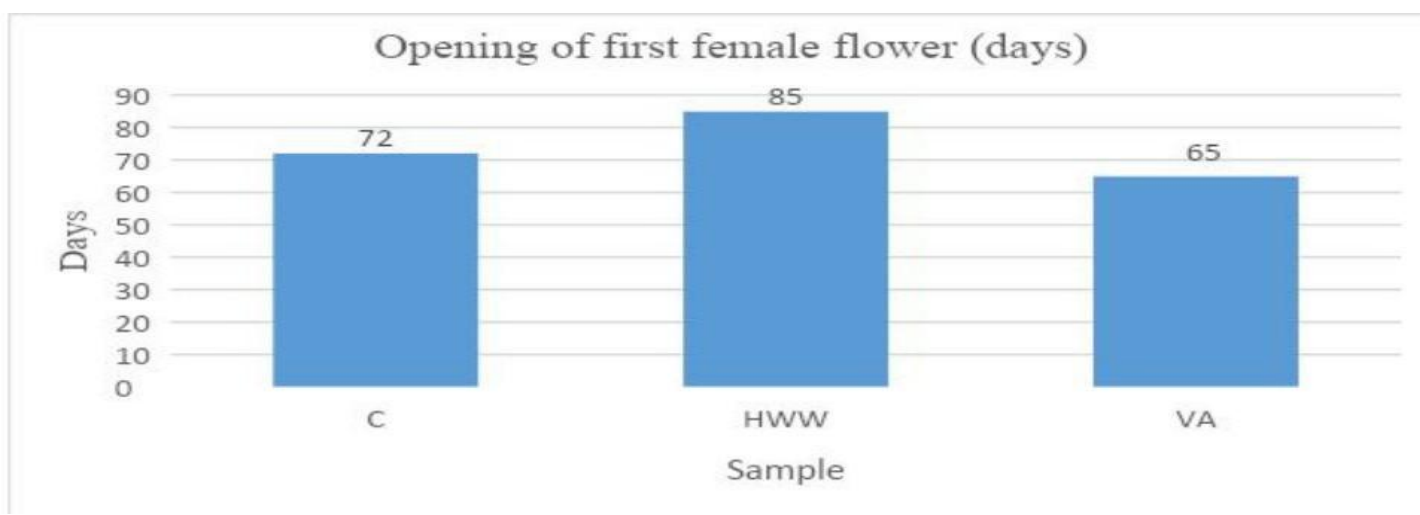

Fig.8 Graphic representation of length of fruit

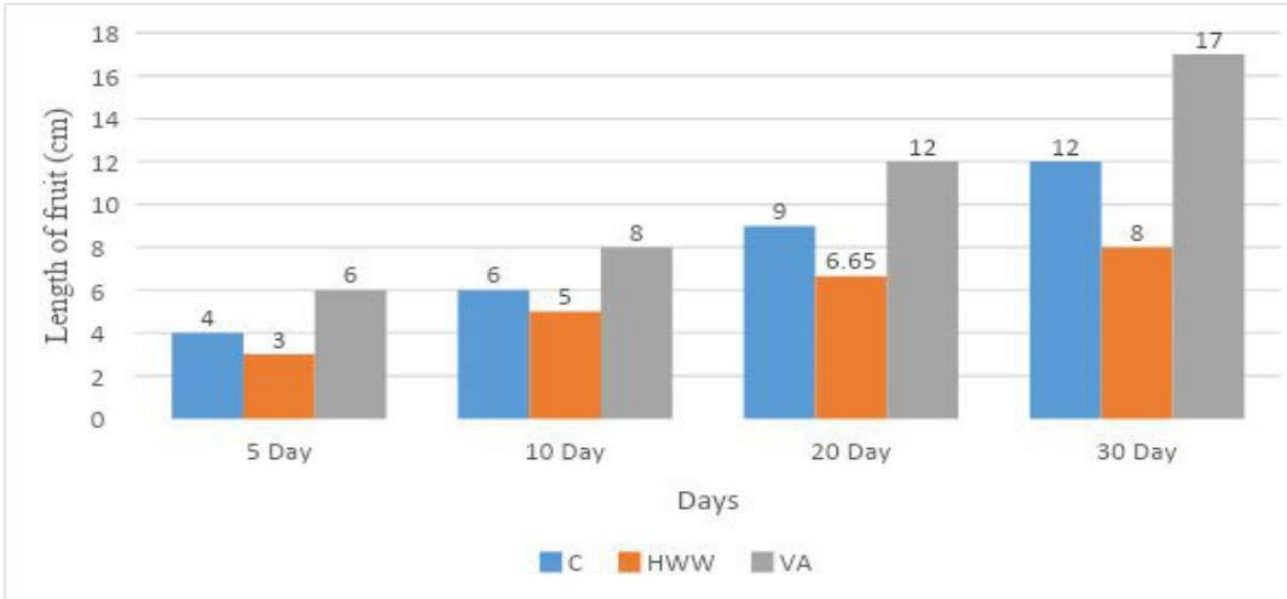

Fig.9 Graphic representation of Width of fruit

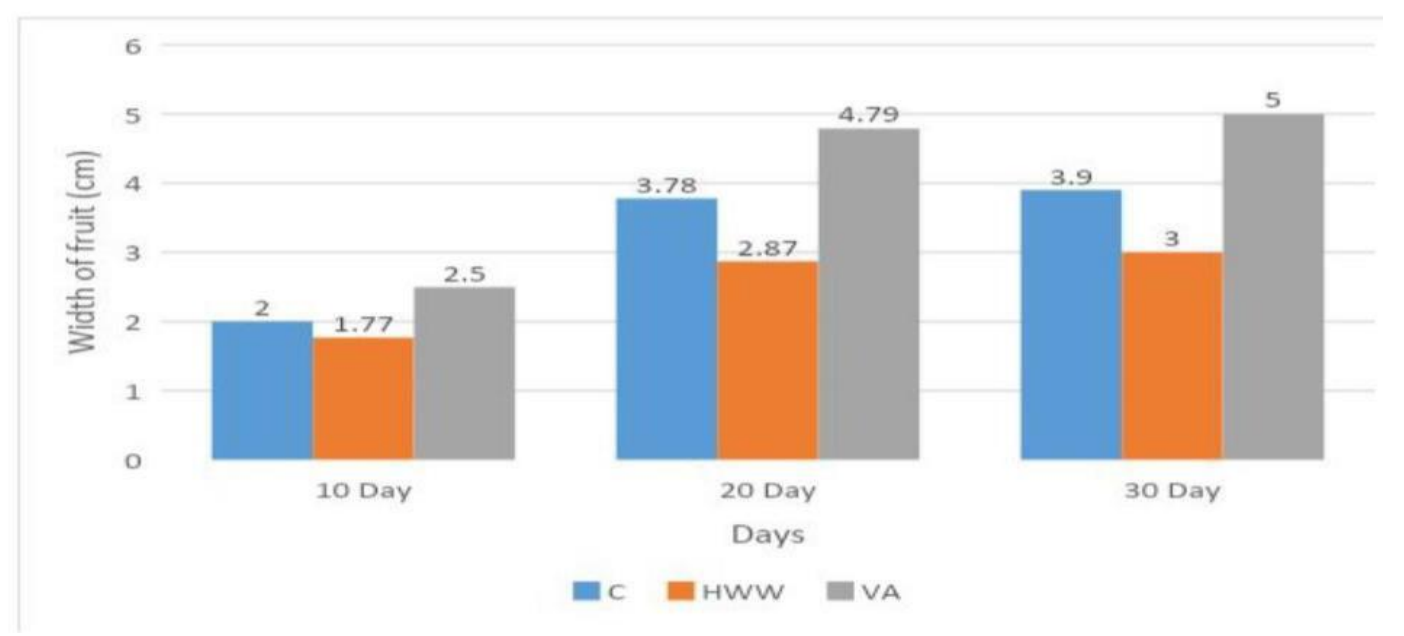


Fig.10 Graphic representation of weight of fruit

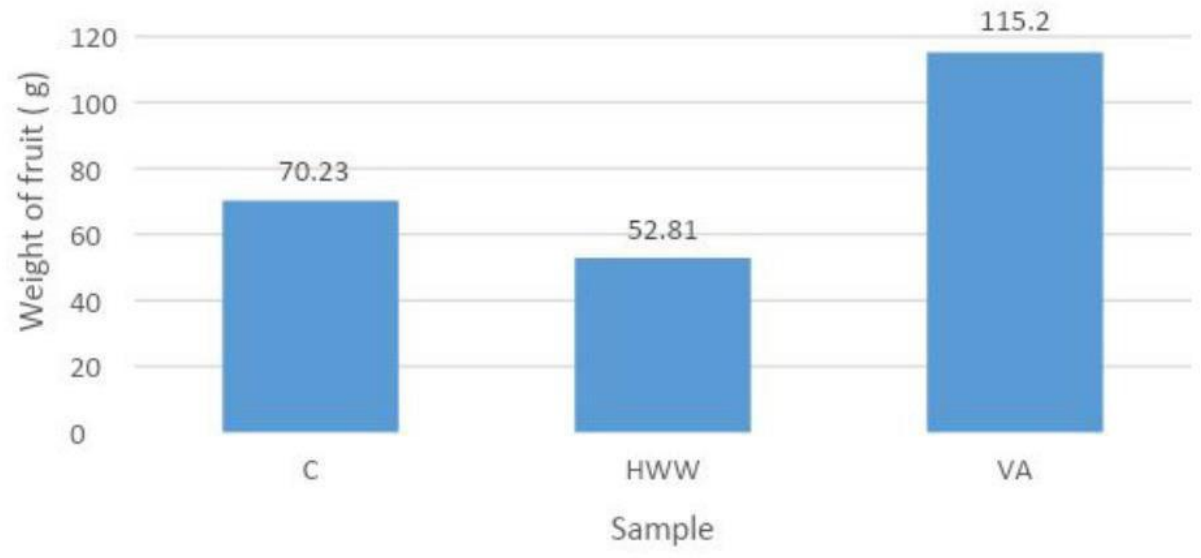

Fig.11 Graphic representation of no. of Seed per Fruit

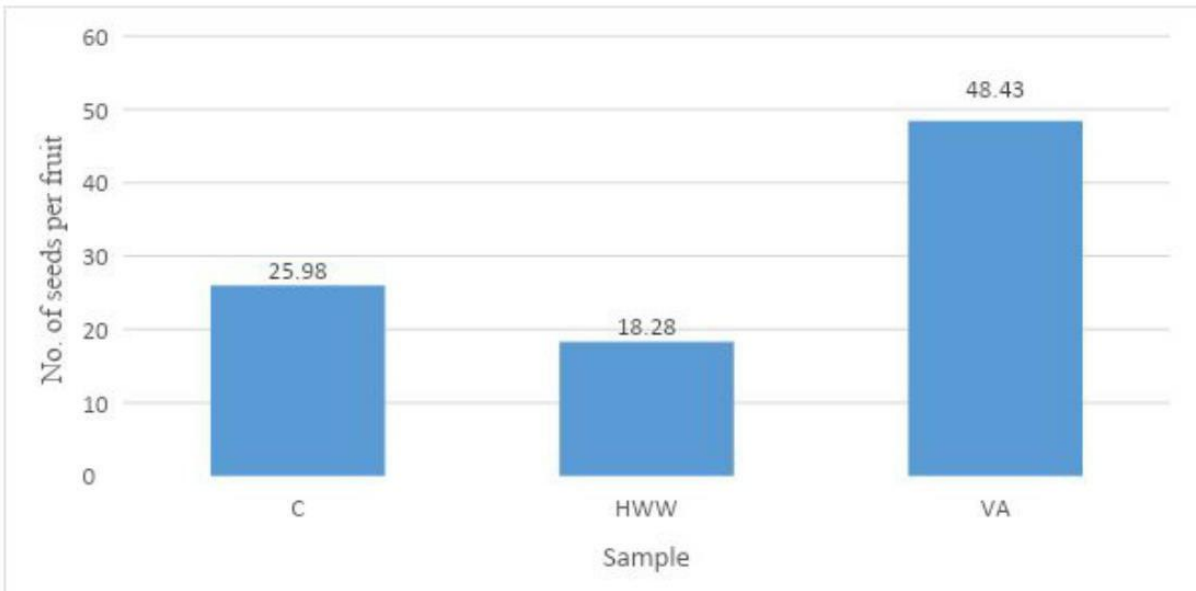

Fig.12 Graphic representation Seed Length and Width

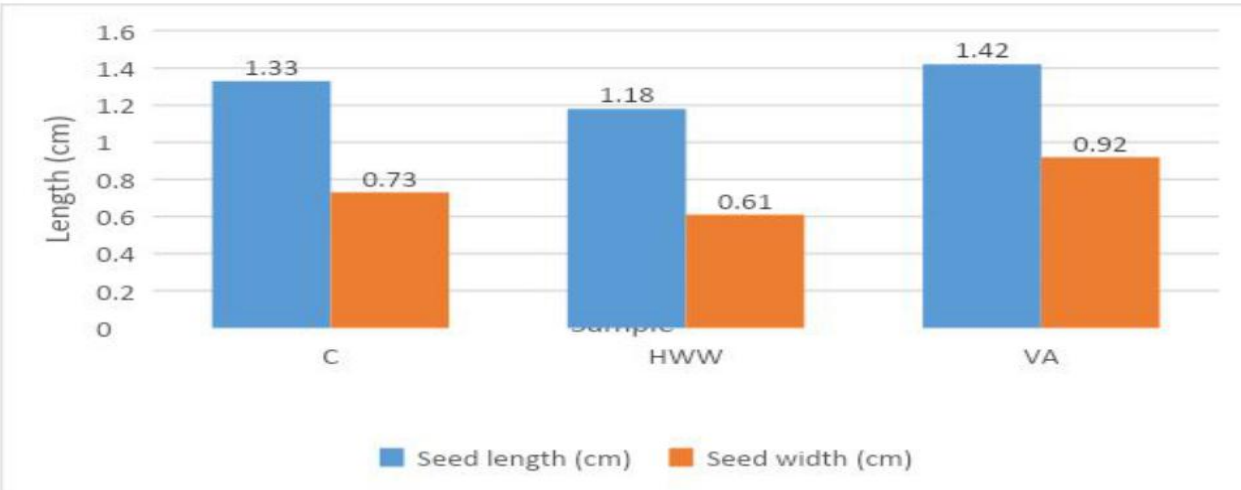


Fig. 13 Graphic representation of Biomass estimation of seed

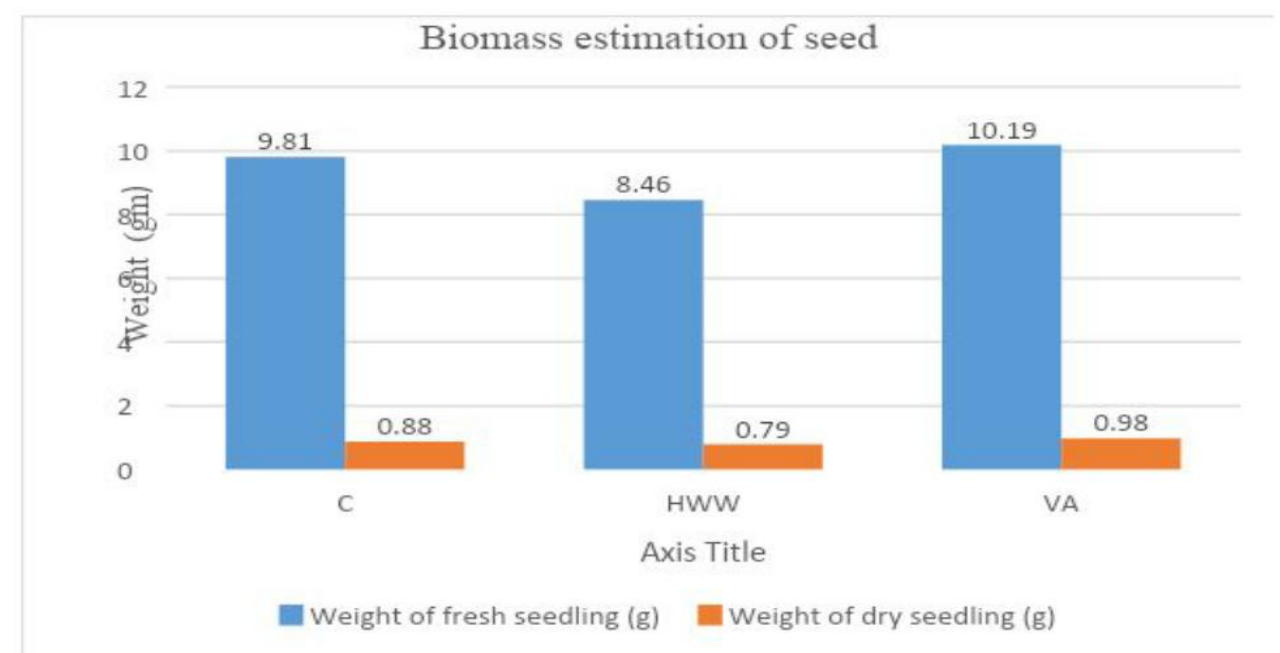

\section{Assessment of number, length and width of seed}

The graphic presentation of number, length and width of Bitter gourd seed was presented in Fig. $11 \& 12$. Number of seed per fruit of vermiaqua treated plant (VA) was 48.43, Hospital wastewater treated plant (HWW) was 18.20 and tap water treated plant (C) was 25.98. Seed length of vermiaqua treated plant (VA) was $1.42 \mathrm{~cm}$, tap water treated plant (C) was $1.33 \mathrm{~cm}$ and and Hospital wastewater treated plant $(\mathrm{HWW})$ was $1.18 \mathrm{~cm}$ whereas seed width of vermiaqua treated plant (VA) was $0.92 \mathrm{~cm}$, Hospital wastewater treated plant (HWW) was $0.61 \mathrm{~cm}$ and tap water treated plant $(\mathrm{C})$ was $0.73 \mathrm{~cm}$. Number of seeds per fruit was significantly higher in vermiaqua treated plant (VA) when compared to Hospital wastewater treated plant (HWW) and tap water treated plant (C). However, seed length and width showed non-significant difference.

\section{Assessment of Bio- mass estimation of seed}

The graphic presentation of Bio- mass estimation of Bitter gourd seedling was presented in Fig. 13. The weight of 10 fresh seedlings of vermiaqua treated water (VA) was $10.19 \mathrm{~g}$, Hospital wastewater treated (HWW) was $8.46 \mathrm{~g}$ and tap water treated (C) was $9.81 \mathrm{~g}$ whereas dry seedlings of vermiaqua treated water (VA) was $0.98 \mathrm{~g}$, Hospital wastewater treated (HWW) was 0.79 $\mathrm{g}$ and tap water treated $(\mathrm{C})$ was $0.88 \mathrm{~g}$.

In conclusion, according to Sir Charles Darwin earthworms are friends of farmers. They are both plant growth promoters. So, Organic farming by using earthworms and their bio-products like vermifiltered wastewater \& vermicompost can provide a sustainable solution to solve various problems created by agrochemicals in farm production all over world. Vermifiltered water is also responsible for the good growth and production of plants. These are disinfecting, detoxifying, neutralized and protective. We have to promote the vermifltration technology by using earthworms for the treatment of wastewater on a commercial scale. It is also an alternative way to save huge groundwater which is ending very fast all over the world. Vermifiltered water or vermiaqua also reduces the use of chemical fertilizers because it is highly nutritive and also NKP rich. 


\section{References}

Arora S, Rajpal A, Kumar T, Bhargava R, Kazmi A A (2014) Pathogen removal during wastewater treatment by vermifiltration. Environ Technol. 35 (17-20): 2493-9. https://doi: 10.1080/09593330.2014.911358.

[PubMed: 25145204].

Bhawalkar U S (1995): Vermiculture Ecotechnology; Publication of Bhawalkar Earthworm Research Institute (BERI), Pune, India.

Carballa M, Omila F, Lema J M, Llompart M, Jares G C, Rodriguez I, Gomez M and Ternes $T$ (2004) Behavior of pharmaceuticals, cosmetics and hormones in a sewage treatment plant. Water Research 38(12): 2918-2926. https://doi.org/10.1016/j.watres.2004.0 3.029.

Dash M C (1978) : Role of earthworms in the decomposer system; In: J.S. Singh and B. Gopal (eds.) Glimpses of Ecology; India International Scientific Publication, New Delhi, pp.399-406.

Ghobadi N, Shokoohi R, Rahmani A R, Samadi M T, Godini $\mathrm{K}$ and Samarghandi M R (2016) Performance of A Pilot-Scale Vermifilter for the Treatment of A Real HospitalWastewater. Avicenna J Environ Health Eng. 3(2):7585. https://doi: 10.5812/ajehe-7585.

Haimi J, Salminen J, Huhta V, Knuutinen J and Palm H (1992): Bioaccumulation of organochlorine compounds in earthworms; J. of Soil Biology \& Biochemistry, Vol. 24 (12), pp. 1699 1703.

Hartenstein R, Neuhauser E F and Collier J (1980): Accumulation of Heavy Metals in the Earthworm E. foetida; Journal of Environmental Quality, Vol. 9; pp. 23-26.

Ireland, M.P. (1983): Heavy Metals Uptake in
Earthworms; Earthworm Ecology; Chapman \& Hall, London.

Kumar C and Ghosh A K (2019) Fabrication of a vermifltration unit for wastewater recycling and performance of vermifltered water (vermiaqua) on onion (Allium cepa). International Journal of Recycling of Organic Waste in Agriculture, 8: 405-415. https://doi.org/10.1007/s40093-0190247-9

Markman S, Guschina IA, Barnsleya S, Buchanan KL, Pascoe D, Muller CT (2007): Endocrine disrupting chemicals accumulate in earthworms exposed to sewage effluents (also garden soils); Cardiff School of Biosciences, Cardiff University, Cardiff, U.K.; J. of Chemosphere, Vol. 70(1): pp.119-125

Pauwels B and Verstraete W, (2006) The treatment of hospital wastewater: an appraisal. J. Water. Health. 4 (4):405416. doi: $10.2166 /$ wh. 2006.025

Samal K, Rajesh Roshan Dash R R and Bhunia P (2017) Treatment of wastewater by vermifiltration integrated with macrophyte filter: A review. Journal of Environmental Chemical Engineering, 5: 2274-2289.

Shokouhi R, Ghobadi N, Godini K, Hadi M, Atashzaban Z (2020) Antibiotic detection in a hospital wastewater and comparison of their removal rate by activated sludge and earthworm-based vermifilteration: Environmental risk assessment. Process Safety and Environmental Protection, 134: 169177.

DOI: https://doi.org/10.1016/j.psep.2019.10. 020

Sinha R K, Bharambe G, Chaudhari U (2008) Sewage treatment by vermifiltration with synchronous treatment of sludge by earthworms: a lowcost sustainable technology over conventional systems 
with potential for decentralization. Environmentalist. 28(4):409-20. https://doi:10.1007/s10669-008-91628.

Sinha R K, Chandran V, Soni B K, Patel U, Ghosh A (2012) Earthworms: nature's chemical managers and detoxifying agents in the environment: an innovative study on treatment of toxic wastewaters from the petroleum industry by vermifiltration technology, Environmentalist 32: 445-452.

Sinha R K, Herat S, Valani D, Chauhan K (2010) Earthworms and ndash; the environmental engineers: review of vermiculture technologies for environmental management and resource development. Int J Global Environ Iss. 2010;10(3/4):265. doi: 10.1504/ijgenvi.2010.037271.

Sinha R K, Misra N K, Singh P K, Ghosh A, Patel U, Kumar J, Hahn G, Soni B K and Prabhune M (2015): Vermiculture Technology for Recycling of Solid Wastes and Wastewater by Earthworms into Valuable Resources for their Reuse in Agriculture (Organic Farming) while Saving Water and Fertilizer; In Dr. Rajeev Pratap Singh \& Abhijit Sirkar (Ed.)
Book Waste Management: Challenges, Threats \& Opportunities'; Chapter 10; pp.233-255; NOVA Science Publications, USA; ISBN 978-1-63482-150-6.

Sinha R K, Patel U, Soni B K \& Li Z (2014): Earthworms for Safe \& Useful Management of Solid Wastes and Wastewaters, Remediation of Contaminated Soils \& Restoration of Soil Fertility, Promotion of Organic Farming and Mitigation of Global Warming: A Review; Journal of Environment and Waste Management, Vol. 1(1), pp. 002-015, May, 2014. (C) www.premierpublishers.org ISSN: 1936-8798

Suarez S, Lema J M and Omil F (2009) Pretreatment of hospital wastewater by coagulation-flocculation and flotation. Bioresour. Technol. 100 (7): 2138-2146. https://doi.org/10.1016/j.biortech.2008 .11. 015 .

Tomar P, Suthar S, (2011) Urban wastewater treatment using vermibiofiltration system. Desalination 282: 95-103. https://doi:

10.1016/j.desal.2011.09.007.

\section{How to cite this article:}

Neha Verma and Ashok K. Ghosh. 2021. Effect of Vermiaqua and Hospital wastewater on Bitter gourd (Momordica charantia L.). Int.J.Curr.Microbiol.App.Sci. 10(01): 1960-1971 doi: https://doi.org/10.20546/ijcmas.2021.1001.228 